\title{
How Teachers Enhance Reading by Blending in Grammar
}

\author{
Sevda Budak ${ }^{*} \quad$ Jenelle Reeves \\ Department of Teaching, Learning, and Teacher Education, University of Nebraska-Lincoln, Lincoln, NE USA \\ E-mail of the corresponding author: sbudak3@gmail.com
}

\begin{abstract}
Reading is a gateway to a world of knowledge and power. However, the language of academic texts is complex in linguistic structure and dense in ideas. For that reason, reading can be an agony for language learners if they do not receive any support. To explore how teachers foster reading by implementing the teaching of grammar, the authors focused on two high school English as a Second Language teachers' thinking and practice. Interpretation of the data revealed that teachers' execution of grammar instruction was influenced by the major factor of timing, which was explored in three main common themes within each case. Based on the emerging findings, the authors discuss the differences and similarities between teachers in their attempts to increase student reading comprehension by strategic approaches to grammar teaching. Within the conclusion, the implications of the study are also highlighted.
\end{abstract}

Keywords: Teacher thinking; grammar; reading; ELL

DOI: $10.7176 / \mathrm{JEP} / 10-15-04$

Publication date:May $31^{\text {st }} 2019$

\section{Introduction}

Reading well grants learners social and cultural capital not only in schools, but also beyond. Being cognizant of the power of reading, expert teachers, who are known for their large repertoire of imagination and improvisational skills, aim to empower their students' skills in reading (Darling-Hammond \& Bransford, 2005). Teaching with English learners adds another layer of complexity - learners reading in a new language in which they are not proficient.

If the purpose is strengthening reading skills, how much of a role the teaching of grammar plays in it? After the third year of primary education, reading becomes an essential tool for learning (Fillmore \& Fillmore, 2013). As the school years move forward, the texts being used become dense in content, and complex in language usage. Therefore, all students, specifically language learners, would need support to see the relationship of language structure being used to convey the information in a given text. As a result, explicit instruction regarding the language usage as an aid to unpack the target content is unarguably warranted.

Consequently, we understand reading as more than a receptive skill. Rather it is one in which learners are actively making meaning in dialogue with texts and images, by internalizing the language structure. As ESL researchers and teachers, we constantly explore the ways to teach the skills of reading to language learners to become competent. Literature shows that a bottom-up approach (decoding skills) to teaching reading was considered initially to be the best; however, the integration of bottom-up and top-down approach (also called interactive approach- reader's background knowledge and guessing skills) has been proposed as a successful way of teaching reading in the recent years (Brown, 2001).

Reading should also be understood for its instructive grammar potential. Language teaching professionals debated on the issues of direct or indirect teaching of a language form. This argument occurs in various forms but share the same idea; explicit or implicit; conscious or subconscious; Focus-on FormS (FoFS) or Focus-on-Form (FoF) ( Ellis, 2012). While some argue the importance of explicit attention to form in context free ways (FoFS), others claim the necessity of teaching form in context dependent ways (FoF) (Nassaji \& Fotos, 2010; Spada \& Lightbown, 2008). How important, then, is the instruction of form in order for reading of a text to be a success for language learners? Which style of focusing on form would be most helpful to ESL readers? Krashen (1993) says extensive reading (free voluntary or pleasure reading) would contribute in gaining linguistic competence, while others recommend a strategic approach to integrate grammar instruction to strengthen reading comprehension (Fillmore \& Fillmore, 2013).

In former years, language-teaching professionals have mostly focused on the teaching of micro-skills (Nassaji \& Fotos, 2010), with the combination of bottom-up and top-down approaches, to foster reading comprehension (Treimen, 2001). Within this model, attention to linguistic properties was recommended, mostly for lower proficiency level students. Yet, the major concern was on extensive reading and helping students meaning-making by mostly concentrating on building background knowledge, the teaching of vocabulary and/or discourse markers. However, intensive reading, which involves particular attention to grammar, was suggested to be not disregarded. The concepts of intensive and extensive readings are parallel to the discussions of FoF instruction proponents, mentioned above. That is, the explicit teaching of language form should be carried out in meaningful contexts, and this explicit teaching of language structure should be executed when/if the need arises, but should always be tied 
to the immediate target content.

Grammar knowledge and its teaching have been considered a fundamental piece in developing language proficiency (Nassaji \& Fotos, 2010). Therefore, researchers have been interested in not only the pedagogical side of teaching grammar, but also teacher cognition. Teachers have some, if not all, decision-making power regarding the teaching of grammar in their classrooms. For that reason, the impact of teacher thinking cannot be ignored. Research that looked into the relationship of teacher thinking and grammar teaching point out the interplay of intricate factors and teacher rationale for engaging grammar instruction. The outcome of the research brought forward that teacher approaches were influenced by their own language learning experiences, and language knowledge, teacher perception of student needs and desire (Borg, 2006; Author 1 \& Author 2, 2015).

Consequently, the majority of language teaching professionals agree about the necessity of minding form in language teaching and learning settings, and literacy development (Fillmore \& Fillmore, 2013; Spada, 2011). Moreover, teachers of ELLs are put in the position of prominence in aiding and developing ELLs' language proficiency and comprehension. Examination of the nature of teachers' thinking about effective, appropriate grammar teaching blended with reading instruction to enhance language learners' reading development seems warranted. Therefore, in this study, we aimed to seek answers to the following questions:

a) What do ELL teachers think about the place of grammar teaching in reading focused lessons?

b) If they do prefer to focus on grammar, how and when do they do that in their lessons?

\section{Method}

The data come from a larger instrumental multiple case study (Stake, 1995), which was designed to explore the nature of teachers' expertise related to form focused instruction. Expert teachers were sought for the study. Participants were selected who had a minimum of five years of teaching experience, advanced educational degrees (master's degree or higher), and the recommendation of the teacher education faculty of the local state university, the district ELL coordinator, and the school principals.

\subsection{Participants}

Of the four participants, we focused on two high school teachers for the purpose of this paper. These two teachers were chosen because of their focus on literacy/reading skills, which they used as a channel to build learners' language proficiency as well as learners' grammar competence. See Table 1 for the characteristic and background description of the teachers.

\subsection{Data Collection}

The data collection process involved classroom observations that ranged between thirty-two to thirty-six hours in total. The data also included post-lesson discussions, semi-structured interviews, conversations, emails, nonparticipant observations, video recordings of the lessons, the stimulated recall technique within the follow-up interviews, and the collection of documents (teacher plans, student work, photographs of the teaching related documents)

\subsection{Data Analysis}

The data were analyzed using MAXqda 11 software program. By using case study template for assigning preselected codes in the code system (Creswell, 2007), emerging 'patterned regularities' were interpreted in specific themes within each case. Following individual case analysis, cross-case analysis was conducted to discuss the similarities and differences of the themes across cases.

To ensure the validity of the data, a triangulation protocol and member checking (Stake, 1995) were used. Classroom observations, interviews, and documents were triangulated to achieve credibility. Member checking is achieved by discussing the themes that emerged from the findings with each teacher.

\section{Findings}

Before looking at each teacher's grammar teaching strategies to foster student reading, we first begin with how each teacher conceptualized grammar and grammar instruction in general.

\subsection{Dan}

Dan was against the sole teaching of grammar to augment learner language competence. 'I don't care so much about their [students'] grammar until it is important for their grammar to be something that somebody is going to evaluate', he expressed. He prioritized enlarging his students' vocabulary repertoire to develop their comprehension skills. As a high school teacher, Dan was concerned that most of his students started their education in the U.S. by missing out on nine years of instruction in the English language. Therefore, Dan's rationale for covering grammar was to teach it in context as needed: 'We don't teach grammar specifically ... we do a lot of that piecemeal as we come across situations in sentences that are on the board or something that we are reading or 
because of what questions that the students might have.'

Dan's grammar teaching was tied to the district's rubric checklist requirements, the main text, Edge, the teacher guidance book, and Grammar and Writing Practice Book as a supplementary material. There were eleven students (six boys and five girls) in Dan's third level reading class that varied in grade levels, linguistic, and cultural background.

The analysis of the data showed that 'timing' was the primary factor in Dan's grammar teaching episodes during reading lessons. That is, Dan's initial concern was whether the grammar was immediately applicable within the target reading text and if that was the case, his mission was 'when' to pull the learners' attention to grammar within the duration of the lesson. We explored this 'when' factor, which we call 'timing' by delineating the major influencing circumstances, and teacher rationale that contributed to it. We discussed these points in three main themes below (See Table 2).

\subsection{Pre-reading}

Dan would target the most salient grammar feature of the text before reading with the intention of two things in mind; to prepare students for the immediate text and to address the deficiencies he detected in his students. For example, one of the texts was about the teenage brain, and Dan thought this selection was a perfect opportunity to address indefinite pronouns due to the nature of the reading. Moreover, he detected that his students needed explicit instruction on proper indefinite pronoun use.

In order to achieve his goal of filling student knowledge gap, Dan believed in activating students' prior knowledge. Therefore, before going in depth with indefinite pronouns, Dan preferred to talk about subjects and predicates to refresh the students' knowledge regarding basic sentence structure. The revision of the essentials of a good sentence, he thought, would prepare his students to see what difference the use of an indefinite pronoun made to the meaning in a sentence. Following an initial detailed study of the target grammar, Dan preferred combining it with the reading text by pulling his students' attention to the target grammar in the text to solidify student comprehension. For example, in the text Teenage Brain, he asked students to find the indefinite pronouns in the sentence:

Until recently, most brain experts thought that the brain stopped growing by the time a person was about 18 months old.

After the students identified until and most as indefinite pronouns, Dan asked about what was suggested with the use of these indefinite pronouns. After hearing a few responses from the students, he provided a detailed explanation:

Most is more than half. If you have 20 doctors that you check with how many of them have to agree with this statement? Would it be 12? Or upper? Yes. If they say, "The brain research from 1820 says....blah blah, that's not recent. Would you like to do research from 1820 or 2012? If it is recent, you are gonna trust it, aren't you? Recently is an important word, but it still is not exact, it is indefinite. When they say most of something you still get an idea, they are making a positive thing, they are making it a thing that you should accept. If it is recently that's fine, you don't need to know exactly, but it is good information. It's happened, we got the research in the last few years and it is not old stuff.

As seen above, Dan's desire to amplify his students' understanding of the form of the text based on his perception of student need, as a preparation for the target text.

\subsection{During Reading}

Dan preferred to attend to grammar as the situation arose such as, a problematic sentence in a text. However, we saw that Dan actually pondered over how and when to teach a specific kind of grammatical structure. We observed this kind of careful thought in the midst of reading as well. Dan attended to grammar explicitly during reading rather implicitly to alert his students' consciousness of the target grammar. For example, while a student was reading the text Jump Away, Dan underlined the words railing, edge, hero, bridge, river, treasure, guide. Then, he started asking questions such as, What kind of a railing is it? What kind of an edge is it? After several responses from the students like, metal railing and cement edge, he started asking about what the words, railing, edge and bridge were called:

Verb, adjective or adverb? A noun is...a person, a place or a thing. Verb is something doing or being. Adjectives, what do adjectives do? Describe nouns... So, a railing is a...a bridge is a .... river is a ...NOUN. What is rushing? It describes the noun. So, it is an adjective.

Dan explained that with this approach he wanted to pull his students' attention to the usage and function of adjectives. Moreover, to complement student understanding, Dan provided a practice sheet consisted of fill-in the blank type of questions from the Grammar Writing and Practice Book. Contrary to his belief in teaching grammar with combination of the text at hand, the practice sheet and the way Dan used it suggested otherwise. For this specific activity Dan's rationalization was that he waited for the 'the right timing' to help the students notice how the use of adjectives alike actually helped visualizing what the author was talking about in the main text. 
Dan had a systematic method for determining how and when to delve into a particular grammar feature during reading. Dan felt the need to provide explicit instruction supplemented with extra practice questions to intensify student comprehension. 'Some of the students expect me to mention the parts of speech; not because I believed that it was necessary for them to know. The knowledge of the meaning of the words is more important', he said. With this statement, then, during reading, we can deduce that Dan utilized explicit grammar teaching mostly based on his perception of student expectation.

\subsection{Post-reading}

Dan also allocated class time to work on certain grammar features after they finished reading to complement his students' understanding of the whole text. His reasoning for these post-text grammar episodes was based on two different factors: the recommendation of the teacher's guide and his perception of the student need. The study of a personal narrative, Karate, would be suitable to clarify these points here. After talking about this particular reading text, the students worked on summarizing the reading by focusing on who, what, when, where and why questions. Then, Dan asked the students what it meant to compare things. He drew a Venn diagram on the board saying:

...that's really good at showing what's the same about doing two things, that's what we look at when we wanna compare things...looking at them side by side and seeing similarities. So, we have the word compare when we look at two things and that's what a diagram looks like...so comparative... the comparative of a word is to say the relationship of one thing to something else. For example, tall is used in the story.

Dan continued on talking about the comparative form of the adjective tall and gave some other adjectives as an example. Then, Dan introduced the term superlative, "you are comparing three things, you are comparing the third to the other two, tall- taller -tallest. Comparative and superlative."

The reason Dan decided to focus on the comparatives was based on the recommendation of the teacher's guide. However, what was notable was that the book was not using the term "comparative." Instead it was talking about the use of adjectives to compare people, places or things. Dan decided to cover both the comparatives and the superlatives by providing the linguistic terms. He said:

I did it because they are going to see that in ACT [American College Testing] or one of the questions could be, Is this a superlative form or a comparative form?...I'm thinking ... when they see -er at the end of a word. Are they gonna know that that's a comparative or superlative?

So, Dan's concern of the kind of grammar knowledge that his students might need shaped his teaching pedagogy as well. And this kind of knowledge involved the awareness of the linguistic terms.

\subsection{Ellie}

Ellie was not a proponent of direct grammar instruction isolated from the target reading. She was more concerned with strengthening comprehension skills and vocabulary knowledge of her students. She clarified her belief by saying, '...grammar will fix itself in time. The purpose of the language is to be able to communicate ideas, and you can do that and be grammatically incorrect.' However, Ellie thought that grammar should still be taught for students to be accurate in their language production. Yet, 'if a student communicates and portrays a meaning and there is some grammatical issues, that is not my huge concern, it is a minor issue', she added.

Ellie preferred attending to grammar in the context of what they were reading. However, she thought certain features of grammar should be taught explicitly. By certain grammar features, she meant complex structures that were hard to grasp without detailed explanation such as 'the present perfect tense.' On those occasions, she said, 'I would do spattered grammar for a couple of days... I take their own work and I type examples without names on it, and we just edit.' Within those 'spattered grammar' activities, she said she would also attempt to use student work to teach the target grammar feature:

... I noticed that... when you use their own writing, something that they produced, that's when they really care...

Elli used the district rubric checklist, the Basic English Grammar book and the main textbook Edge. Her level three classroom consisted of fourteen students, five girls and nine boys, who varied in their cultural and linguistic backgrounds. Data showed that Ellie's decisions around how and when to teach grammar depended on various factors; yet similar to Dan, all the influencing variations revolved around the 'when' factor, which is explored in three main themes below (See Table 3).

\subsection{Pre-reading}

Ellie's intention of challenging her students was the primary factor in attending to grammar before reading. If her students had already mastered the target form of the immediate text, Ellie would arrange grammar activities that were slightly beyond the students' proficiency level to challenge her students. For example, for the text, Heartbeat, the recommendation of the book was to teach regular past tense verbs. Based on her knowledge of her students, Ellie thought that they had already known the regular past tense verbs. Therefore, she decided to introduce the 
adjectives that might look like a regular verb. She knew that identifying adjectives that might also be used as a verb in a sentence would be a challenge for her students:

Many of them would say it is a verb when they see, say packed, in a sentence because it ended with an -ed. It can be a verb and it can be an adjective.

Overcoming boredom also lies under Ellie's intention of challenging. Instead of going over familiar skills, Ellie aspired to broaden student grammatical knowledge by enriching it with new knowledge beyond student current level. Recognizing the importance of context, she blended grammar instruction with the target reading text. For example, to show the difference between verbs and an adjectives that ended in -ed, Ellie chose four words from the reading text - packed, smushed, defined, frustrated- that were used as adjectives in sentences or asked her students to identify adjectives that looked like verbs in another reading text. Ellie did not want her students to think of grammar as a separate entity, but rather as a part of the language that they were reading in. She wanted her students to be aware of how a language structure works in an authentic text. She did not worry about whether her students would use them correctly in their language production, as she thought that it would come in time eventually.

Many times Ellie decided on what grammar feature to study depending on the objectives of a reading text. She preferred pointing it out while reading a text as explained below.

\subsection{During Reading}

Ellie believed in addressing certain grammar points that were part of the reading text while her students were interacting with the immediate text. Her goal was to increase her students' noticing skills of the target grammar point within a meaningful context. For example, the objectives of the text, The Bulk, was about making inferences and working on the points of view. Ellie thought that she should touch on the subject pronouns as well. After forming two different groups based on student preferences, Ellie asked them to interact with the text by answering the questions in the book. Initially, Ellie asked what "point of view" meant. After defining it, she asked the students to find a pronoun, which showed that the article was written in the third-person point of view. The group interaction went as follows:

Ellie: What is first person?

Student 1: Character

Student 2: That guy in the story.

Student 3: The guy in the story who tells the story

Ellie: So, what words would he use?

Student 1: I

Student 4: My

Ellie: $M e$ and may be $u s$. All of these are gonna show that these are first person. A pronoun is a word that can take place of a name, pronoun is like who, ok. What is second person? Your mom is yelling at you. She points her finger and says.....Ku, you!

Ellie: So, You or your. What would we say for third person? He, she, it, they, their, his hers, Right ?

As seen above, the first strategy Ellie preferred using was attempting to elicit the right answer from her students. With the use of question and answer format, Ellie also tended to provide explicit information about the target grammar feature while adding to what students already knew. For example after introducing the pronouns as given in the lesson segment above, one student said that the name "Craig" would also show that the text was written in the third person. Ellie expanded on this answer as follows:

Using a name is third person, too, but it is not a pronoun. Ok. So, I have Craig, he and his so far. Which one of those three is a pronoun? So, what is a noun? A noun is a person, place or thing. So, we are talking about which one of those? A person, right? A pronoun is a word that can take the noun away. So, what word can we use when we take Craig away?

Addressing student struggle was another driving force in Ellie's grammar related decision making, which mostly occurred after reading. However, the type of teaching she used was not always tied to a text at hand due to several reasons which are discussed below.

\subsection{Post-reading}

When the reading texts either did not require a certain grammar feature to be taught or were hard to combine with any grammar related activities, Ellie preferred arranging grammar lessons to address student knowledge gaps based on her perception. For example, Ellie observed that some of her students were not using the present perfect tenses correctly. Moreover, she thought the study of those tenses would be an opportunistic follow-up of the previous unit, which focused on the simple past tense. Being a proponent of Input Theory, she wanted to take it "one step further" by including since and for:

I looked for something that I see them struggling with. ...For example, today the girl's sentence said, "they have been came." They do not know what formed with the verb in after been. Have been married why is that one 
in the past tense versus have been playing soccer. It is just something that they struggle with.

Based on the data, we see the thoughtful decision-making behind each of Ellie's actions regarding grammar teaching in reading based lessons. What is worthy of noticing here is that Ellie's deliberate thinking constitutes not only the concern of 'How can I make it harder and more valuable?', but also the factor of timing, which will be visited later in the paper. In the following section, we now re-examine each case by discussing the convergences and divergences between the two teachers' thinking and practice.

\section{Cross-Case Theme Analysis}

The cross-case theme analysis of the two teachers showed both similarities and differences in their stated thoughts and practice regarding blending grammar in reading. In Table 4, the findings of this analysis were outlined.

Previous research shows that the discrepancies between teachers' stated beliefs and their actions are based on various contextual factors (Borg, 2006). In this study, both teachers stated that they were not concerned with grammar knowledge of their students and prioritized increasing comprehension and improving vocabulary knowledge of their students in reading lessons. However, they did not or could not ignore grammar. In this study, for example, although Ellie expressed that grammar did not deserve explicit attention, she also mentioned that explicit instruction to grammar was still inevitable, since certain structures in English have to be taught explicitly to foster student understanding of the meaning in the text. Dan did not put into words that grammar needed to be taught for certain occasions; yet, the way he attended to grammar in his lessons suggested this was one of his guiding beliefs about grammar. He insinuated the need to teach grammar during reading by saying, 'I don't care so much about their [students] grammar until it is important for their grammar to be something that somebody is going to evaluate.

While teachers' decisions regarding grammar-teaching within reading point to the situational nature of teaching (Tsui, 2003), it also shows these teachers' full consciousness regarding when, why and how to teach grammar to support student comprehension of the target text. Researchers claimed that grammar should be treated either within or as a continuation of the immediate context to make the study of grammar more meaningful (Spada \& Lightbown, 2008). These claims were reflected on these teachers' practice as they tried to address grammar not as a separate entity, but rather a structure that creates meaning.

Despite their preference to teach grammar in the context of reading text, certain circumstances would lead these teachers to attend to grammar in context free ways. These circumstances mostly revolve around the teacher perception of student needs or deficiencies. Research has confirmed that explicit instruction can solidify student understanding of form to aid comprehension (Spada, 2011). In this study, both teachers spent time to cover certain grammar features to close student knowledge gap, mostly during post-reading. However, these teachers looked for ways to connect the target form with the readings to make them meaningful and retainable.

Moreover, there were differences in the ways the teachers attended to grammar to assist reading comprehension. One of the conspicuous difference was that Ellie constructed her grammar input lessons slightly more advanced than the students' current level; for, she thought it would be more stimulating to her students. Dan, on the other hand, valued reasoning. He provided rationale for each grammar study to justify why it was important for the students to learn them. He would also emphasize the knowledge of linguistic terms as he thought the students might face with these terms in standardized test questions. Research regarding teacher thinking shows that teachers preferred teaching technical terms based on their perception of student expectation (Burgess \& Etherington, 2001). Reading professionals also find the knowledge of the rules necessary to help language learners understand complex sentences to strengthen comprehension (Fillmore \& Fillmore, 2013).

\section{Conclusion}

In conclusion, the principal question that framed this paper was teacher thinking and practice regarding grammar teaching to foster reading comprehension. While the main concerns of the reading lessons are to improve comprehension and vocabulary knowledge, this study showed that teachers believed in the impact of deliberate grammar teaching in comprehension, which was also supported in research and by reading scholars (Akbari, 2014; Fillmore \& Fillmore, 2013). This particular outcome is worth noting as it contradicts scholars who claim reading itself as the sole contributing factor in comprehension compared to formal instruction (Lee, Krashen, \& Gribbons, 1995).

Moreover, the findings revealed that teachers considered the timing of aligning the teaching of grammar with reading as important. The opportunities in the text, teacher perception of student needs before, during, and after reading, and the aim of challenging students are the determining factors that set the concept of 'right timing' for an effective grammar teaching to strengthen reading. Teacher conceptualization of timing is important here as it is also one of the prominent concepts that attracts the researchers' attention, who call for more study to explore the timing concept in detail (Spada, 2011).

At present, the empirical studies that looked into the impact of grammar in reading comprehension have shown divergent results mostly due to the research design (Zhang, 2012). Yet, teachers of English do consider the 
necessity of studying and integrating grammar to assist comprehension, and they recommend creating a balance between language form and meaning by mostly focusing on the timing of form instruction in combination with the target reading (Anderson, 2006; Stanford, 2006).

Form focused instruction research show that any grammar teaching option, explicitly or implicitly, could be implemented within a meaningful context if the teachers see the need to (Spada, 2011). Reading scholars also confirm the necessity of grammar knowledge in meaning making (Grabe, 2009). We see that these recommendations were all evident in the teachers' stated thoughts and strategies of this study.

This paper would appeal to the audience of the reading research and ELL community, as it shows the interplay between ELL teacher thinking and practice regarding grammar teaching implemented in reading. As supported by form-focused instruction theory, and reading scholars' recommendation attention to form cannot be ignored at the expense of meaning or vice versa. And this study explicitly shows the manifestations of the research claims in the teachers' practice by delineating when and how they attended to grammar in their reading lessons.

The language used in school texts constitutes complex structures and are dense in meaning compared to oral language. Therefore, reading scholars call for teacher support to help students unpack the relationship between intricate grammatical structures and their function in a text to assist student understanding (Fillmore \& Fillmore, 2013). Even though teachers are convinced in the efficacy of integrating grammar at strategic times and in various ways, further research should be carried out that look into the impact of grammar teaching within reading focused lessons. Furthermore, future research studies can also focus on students to examine which kind of particular instruction they are open to and when to assist their reading comprehension.

The teachers of language learners at least in this study acknowledge the role of grammar in comprehension and they invest in strategic grammar teaching approaches by blending in reading. It is claimed that teachers "[fail] to recognize the role played language itself in literacy" (Fillmore \&Fillmore, 2013; p.1); therefore, we propose that teacher educators should give more effort to spread studies of teacher thinking regarding grammar blended in reading and the varies approaches that were carried out, and believed to be effective. Based on our classroom observations and interviews with language teachers, we at least take pleasure in knowing and informing the readers that there are teachers who acknowledge the impact of grammar teaching by investing time and aligning their approach to help students make meaning in a deeper level in a given text. We are confident that there are more teachers out there, if only their voices are heard.

\section{References}

Akbari, Z. (2014). The role of grammar in second language comprehension: Iranian ESP context. Procedia-Social and Behavioral Sciences, 98, 122-126.

Anderson, J. (2006). Zooming in and zooming out: Putting grammar in context into context. The English Journal, 95(5), 28-34.

Borg, S. (2006). Teacher cognition and language education. Continuum, London.

Brown, H. D. (2001). Teaching by principles. An interactive approach to language pedagogy. NY: Pearson.

Burgess, J., \& Etherington, S. (2002). Focus on grammatical form: Explicit or implicit? System, 30(4), 433-58.

Creswell, J. W. (2007). Qualitative inquiry \& research design: Choosing among five approaches. (2 ${ }^{\text {nd }}$ ed.). Thousand Oaks, CA: Sage.

Darling-Hammond, L., \& Bransford, J. (2005). Preparing teachers for a changing world: What teachers should learn and be able to do. San Francisco, CA: Jossey-Bass

Ellis, R. (2012). Language teaching research and language pedagogy [Nook Color version]. Retrieved from barnesandnoble.com/u/NOOK-Book-ebook-store/379003094

Fillmore, L.W., \& Fillmore, C. J. (2013). What does text complexity mean for English learners and language minority students? Understanding Language. Retrieved 14 July 2015, from http://ell.stanford.edu/publication/what-does-text-complexity-mean-english-learners-and-languageminority-students

Grabe, W. (2009). Reading in a second language: Moving from theory to practice. New York: Cambridge University Press.

Krashen, S. (1993). The power of reading. Englewood, CO: Libraries Unlimited.

Lee, Y.O., Krashen, S., \& Gribbons, B. (1995). The effect of reading on the acquisition of English relative clauses. ITL: Review of Applied Linguistics 113-114, 263-273.

MAXQDA, software for qualitative data analysis, 1989-2013, VERBI Software - Consult - Sozialforschung $\mathrm{GmbH}$, Berlin, Germany.

Nassaji, H., \& Fotos, S. (2010). Teaching grammar in second language classrooms: Integrating form-focused instruction in communicative context. Taylor \& Francis. Retrieved 1 February 2012, from <http://0lib.myilibrary.com.library.unl.edu?ID $=304479>$

Spada, N. (2011). Beyond form-focused instruction: Reflections on past, present and future research. Language Teaching, 44(2), 225-236. 
Spada, N. \& Lightbown, P.M. (2008). Form-focused instruction: Isolated or integrated? TESOL Quarterly, 42(2), 181-207.

Stake, R. E. (1995). The art of case study research. Thousand Oaks, CA: Sage Publications.

Stanford, B. (2006). "Somebody died?" Using grammar to construct meaning in adolescent literature. The English Journal, 95(5), 60-64.

Treiman, R. (2001). Reading. In M. Aronoff and J. Rees-Miller (Eds.), Blackwell Handbook of Linguistics (pp. 664-672). Oxford, England: Blackwell.

Tsui, A.B.M. (2003) Understanding Expertise in Teaching. Cambridge: Cambridge University Press.

Zhang, D. (2012). Vocabulary and grammar knowledge in second language reading comprehension: A structural equation modeling study. The Modern Language Journal, 558-575.

Table 1. Characteristics and Background of the Teachers

\begin{tabular}{|c|c|c|}
\hline & Dan & Ellie \\
\hline Schools & Blue Moon High School & Light High School \\
\hline Years of Experience & $25 / 10$ in $\mathrm{ELL}$ & $8 / 2$ in ELL \\
\hline Grades & $9-12$ & $9-12$ \\
\hline \multirow[t]{5}{*}{ Educational Degrees and Certifications } & English & Spanish \\
\hline & Ell Endorsement & M.A. \\
\hline & Reading Recovery \& & \\
\hline & An Administrative Certificate & \\
\hline & M.A & \\
\hline \multirow[t]{4}{*}{ Teaching Background } & Taught all levels & Bilingual \\
\hline & The last four years at a high school & Taught Spanish for 8 years \\
\hline & Teaching reading and writing & Taught Ell levels 1,2, and 3 \\
\hline & & Teaching reading \\
\hline
\end{tabular}

Table 2. Overall Themes for Dan

\begin{tabular}{|l|l|}
\hline The Timing & Rationale \\
\hline Pre-reading & To increase student awareness of the target grammar feature \\
\cline { 2 - 2 } & To complement student lack of knowledge \\
\hline \multirow{5}{*}{ During Reading } & To enable students to see how language works in the text \\
\cline { 2 - 2 } & To increase student noticing skills \\
\cline { 2 - 2 } & To foster student meaning-making \\
\cline { 2 - 2 } & To respond to student expectation \\
\hline Post-reading & To complement student understanding of the whole text \\
\hline
\end{tabular}

Table 3. Overall Themes for Ellie

\begin{tabular}{|l|l|}
\hline The Timing & Rationale \\
\hline Pre-reading & To challenge students by going beyond their current proficiency levels (i+1 theory) \\
\hline During Reading & To foster student noticing skills of the target grammar in the text \\
\cline { 2 - 2 } & To foster student meaning-making \\
\hline Post-reading & To address student struggle and knowledge gaps \\
\hline
\end{tabular}

Table 4. Similarities and Differences

\begin{tabular}{|l|l|l|}
\hline \multirow{2}{*}{ Teacher Thinking } & Dan & Ellie \\
\hline & Grammar is not vital in reading & Grammar is not essential, it will come in time \\
& $\begin{array}{l}\text { Comprehension and vocabulary are } \\
\text { essential }\end{array}$ & Communication of ideas is more important \\
\cline { 2 - 3 } & $\begin{array}{l}\text { Grammar should be attended to to } \\
\text { increase comprehension }\end{array}$ & $\begin{array}{l}\text { Grammar should be taught to increase } \\
\text { comprehension }\end{array}$ \\
\cline { 2 - 3 } & $\begin{array}{l}\text { Grammar teaching is necessary for complex } \\
\text { structures }\end{array}$ \\
\hline $\begin{array}{l}\text { Execution } \\
\text { grammar teaching } \\
\text { to enhance reading }\end{array}$ & $\begin{array}{l}\text { Grammar teaching occurs pre-reading, } \\
\text { during reading and post-reading }\end{array}$ & $\begin{array}{l}\text { Grammar teaching occurs pre-reading, } \\
\text { during reading and post-reading }\end{array}$ \\
\cline { 2 - 3 } & Isolated grammar teaching occurs & Isolated grammar teaching occurs \\
\cline { 2 - 3 } & Focuses on linguistic terms & The application of i+1 theory \\
\hline
\end{tabular}

